\title{
Multi-Period Multi-Criteria Decision Making under Uncertainty: A Renewable Energy Transition Case from Germany
}

\author{
Tobias Witt ${ }^{1, *(1)}$ and Matthias Klumpp ${ }^{1,2,3}$ (D) \\ 1 Chair of Production and Logistics, Georg-August-University of Göttingen, Platz der Göttinger Sieben 3, \\ 37073 Göttingen, Germany; matthias.klumpp@uni-goettingen.de \\ 2 Institute for Logistics and Service Management (ild), FOM University of Applied Sciences, \\ 45141 Essen, Germany \\ 3 Fraunhofer Institute for Material Flow and Logistics (IML), 44227 Dortmund, Germany \\ * Correspondence: tobias.witt@uni-goettingen.de
}

check for updates

Citation: Witt, T.; Klumpp, M. Multi-Period Multi-Criteria Decision Making under Uncertainty: A Renewable Energy Transition Case from Germany. Sustainability 2021, 13, 6300. https://doi.org/10.3390/ su13116300

Academic Editor: Raffaele Carli

Received: 6 April 2021

Accepted: 26 May 2021

Published: 2 June 2021

Publisher's Note: MDPI stays neutral with regard to jurisdictional claims in published maps and institutional affiliations.

Copyright: (c) 2021 by the authors. Licensee MDPI, Basel, Switzerland. This article is an open access article distributed under the terms and conditions of the Creative Commons Attribution (CC BY) license (https:// creativecommons.org/licenses/by/ $4.0 /)$.

\begin{abstract}
Methods of multi-criteria decision making (MCDM) from operations research have been applied to provide information for making long-term decisions in the energy sector, and energy policy. For example, in sustainability evaluations, multiple conflicting criteria can be considered. While most MCDM approaches have been applied to evaluate energy systems in a single period, the multi-criteria evaluation of energy system evolution over time has received less attention. To evaluate such transition paths, multi-period MCDM approaches can be used. Because of long-term planning horizons, deep uncertainties need to be considered. Based on prior multi-period MCDM approaches, this paper provides an extension of the outranking approach preference ranking and organization method for enrichment evaluations (PROMETHEE) for multi-period evaluations in deep uncertainty settings. In order to adequately address the consideration of uncertainties and to obtain an additional level of information, a multi-period PROMETHEE approach and scenario planning are combined. In an illustrative example, this method is applied to a case study from the German energy sector regarding a renewable energy transition. This highlights the potential interactions of a multi-period perspective and the consideration of external scenarios in the decision-making process.
\end{abstract}

Keywords: multi-period evaluation; PROMETHEE; deep uncertainty; scenario planning; energy transition

\section{Introduction}

Energy scenarios describe possible future states or developments of energy systems, and are often applied to provide orientation regarding decisions in energy policy and the energy sector, for example in planning the energy transition towards renewable resources [1-4]. In most cases, the major objective of an energy transition is to achieve a more sustainable energy system [5-7]. Multi-criteria decision analyses, especially approaches from multi-attribute decision making (MADM), which evaluate a finite and discrete number of alternatives, have been applied in combination with energy scenarios; this achieves more transparent decision support processes, helps to structure complex decision problems, and provides the basis for making informed decisions [8-12]. MADM approaches can provide decision support for and have long been applied in complex decision problems, such as the evaluation of sustainability, which are characterized by conflicting criteria measured in incommensurable units (see [6,13-18]). By aggregating decision-relevant information, MADM approaches provide the basis for an analysis, comparison, and ranking of alternatives, and eventual selection of the best option. To compare different alternatives for future energy systems regarding their sustainability, the sustainability objective is often operationalized with technical, economic, environmental, and social criteria [6]. For example, carbon dioxide or greenhouse gas emissions are measured as a major political reduction challenge for global climate protection [19-23]. With the help of energy system 
models, the performance of the alternatives is measured against these criteria, yielding performance scores for each alternative and each criterion. MADM methods, such as MAUT [24], PROMETHEE [25], AHP [26], or ELECTRE [27] provide structured procedures for evaluating these performance scores, while decision makers' preferences can be considered. They can help to structure and clarify political debates, as they can be useful in pointing out the most essential issues and aiding in eliciting decision makers' preferences and values $[28,29]$.

Evaluations of energy scenarios usually regard a specific time or period, e.g., the year 2050, which we refer to as a single-period (SP) analysis. However, such studies do not investigate potential paths for making the transition to the desired future state, e.g., a sustainable energy system, as a dynamic decision problem. In contrast, solving dynamic multi-criteria decision problems necessitates an explicit modelling of dynamic aspects in a decision problem, i.e., changes over different periods [30]. In contrast to the single-period analyses, we call these multi-period (MP) analyses. For decision makers in energy policy, it would be interesting to investigate the question, how to reach desirable future states and consequently evaluate transition paths spanning several periods in order to set suitable year-specific energy policy targets, e.g., emission reductions or capacity extensions of renewable energy technologies [31]. In the context of energy systems planning, multiperiod (MP) energy system models have long been used to investigate a system's behavior over multiple periods [32] and thus can provide input for MP MADM approaches. In this case, using an SP evaluation may lead to loss of information, because data need to be aggregated and intermediate periods cannot be considered. Some MP MADM approaches have already been proposed in the research literature (see next section). For strategic decisions with long planning horizons, investigating the effect of uncertainties is often integrated in decision support [33-35]. The uncertainty associated with decision problems regarding the energy transition is usually categorized as deep uncertainty, meaning that "decision makers, analysts, and experts do not know or cannot agree on the system model(s), the probability distributions for inputs to the system model(s) and their interdependencies, and/or the value systems used to rank alternatives" [36]. Decision problems with deep uncertainties include internal uncertainties, relating to the process of problem structuring and analysis, and external uncertainties, regarding the nature of the environment and thereby the consequences of a particular course of action which may be outside of the control of the decision maker [37]. Approaches for modelling internal uncertainties include fuzzy sets [38] (see [39] for a review regarding applications in energy policy planning) and rough sets [40]. However, internal uncertainties should ideally be resolved at the problem-structuring phase or, where not resolvable, with suitable sensitivity analyses [37], which is why we focus on external uncertainties in this paper. The combination of scenario planning and MADM approaches is considered to be particularly useful for considering external uncertainties [10,37].

So far, the proposed MP MADM approaches are not adequate in a deep uncertainty setting, because they are based on probability distributions for uncertain aspects, or they do not consider uncertainties at all. One solution may be to combine the MP MADM approach with scenario planning techniques, which do not necessarily require the definition of scenario probabilities [41-43]. Some approaches combining multi-criteria decision analysis with scenario planning already exist (see [35] for a review). However, to our knowledge, the combination of MP MADM approaches and scenario planning-without the specification of probabilities - has not been investigated yet. Specifically, we use the scenario concept described by [44], so that scenarios are a comparatively different and systemized set of future-oriented, plausibly possible, narrative descriptions about the external context of a decision problem. Hence, the objective of this paper is to describe a MP MADM approach based on the outranking method PROMETHEE for making strategic decisions in the energy sector, in combination with scenario planning. The contribution of this paper can be described as: (a) proposing the new method for evaluating alternatives under deep uncertainty in a MP MADM setting (MP-PROMETHEE-S) and (b) presenting results for the 
case study of the transition of a local energy system in Germany. The new method advances previous MP MADM methods, as uncertain developments of preference scores over time can be evaluated with the help of scenarios. The results for the decision problem in the case study also enrich the results of previous studies with the consideration of uncertainties and an evaluation of robustness.

The paper is structured as follows: In the following Section 2, the literature on MP MADM approaches is summarized. In Section 3, notation, assumptions, and procedure of MP-PROMETHEE-S is described, based on the standard PROMETHEE approach. Furthermore, MP-PROMETHEE-S is applied in Section 4, in a re-evaluation of planning the green transition of the power generation system in a German town from 2000 to 2020 in five different scenarios. Section 5 provides a detailed discussion of the developed method and its application in the case study. Concluding remarks and possible further research questions are placed in the final Section 6.

\section{Literature Review: MP MADM Approaches}

In energy system analysis, MP energy system models have long been used and are well-established [45,46]. However, suitable approaches for MP MADM approaches have emerged mostly in the recent decade, and applications in the energy sector are limited, even though there are many applications that combine energy system analysis and SP MADM approaches (for a review, see [6]). In the following, we provide an overview of seven MP MADM approaches, summarized in Table 1.

Table 1. Overview of MP MADM approaches.

\begin{tabular}{|c|c|c|c|c|c|c|}
\hline References & MADM Algorithm & MP Aggregation & $\begin{array}{l}\text { Uncertainty } \\
\text { Consideration }\end{array}$ & $\begin{array}{l}\text { Criteria } \\
\text { Weights }\end{array}$ & $\begin{array}{c}\text { Path } \\
\text { Dependency }\end{array}$ & Specific Features \\
\hline [47] & Generic & Not specified & No uncertainties & Dynamic & Not considered & $\begin{array}{c}\text { Group } \\
\text { decision-making }\end{array}$ \\
\hline [48] & Generic & Decision tree & $\begin{array}{l}\text { Probabilities } \\
\text { of scenarios }\end{array}$ & Static & $\begin{array}{l}\text { Modeled } \\
\text { explicitly }\end{array}$ & \\
\hline [49-52] & $\begin{array}{l}\text { Single synthesizing } \\
\text { criteria approach }\end{array}$ & $\begin{array}{c}\text { Confidence levels } \\
\text { of periods }\end{array}$ & $\begin{array}{l}\text { Probabilities } \\
\text { of scenarios }\end{array}$ & Static & Not considered & \\
\hline [53] & Generic & Not specified & Not specified & Static & $\begin{array}{l}\text { Modeled } \\
\text { explicitly }\end{array}$ & \\
\hline [54] & PROMETHEE II & $\begin{array}{l}\text { Confidence levels } \\
\text { of periods }\end{array}$ & No uncertainties & Static & Not considered & $\begin{array}{l}\text { Varying thresholds } \\
\text { in preference } \\
\text { functions }\end{array}$ \\
\hline [55] & PROMETHEE I & $\begin{array}{l}\text { Confidence levels } \\
\text { of periods }\end{array}$ & $\begin{array}{c}\text { Monte Carlo } \\
\text { simulations of } \\
\text { performance scores }\end{array}$ & Static & Not considered & \\
\hline [56] & PROMETHEE II & $\begin{array}{l}\text { Arithmetic mean, } \\
\text { weighted average } \\
\text { (confidence levels of } \\
\text { periods), mean of } \\
\text { discounted net flows }\end{array}$ & No uncertainties & $\begin{array}{l}\text { Static or } \\
\text { dynamic }\end{array}$ & $\begin{array}{l}\text { Modeled } \\
\text { explicitly }\end{array}$ & $\begin{array}{l}\text { Varying thresholds } \\
\text { in preference } \\
\text { functions are } \\
\text { aggregated }\end{array}$ \\
\hline [57] & PROMETHEE II & $\begin{array}{l}\text { Arithmetic mean or } \\
\text { weighted average }\end{array}$ & No uncertainties & $\begin{array}{l}\text { Static or } \\
\text { dynamic }\end{array}$ & Not considered & $\begin{array}{l}\text { Weighting factor for } \\
\text { MP aggregation can } \\
\text { include a discount }\end{array}$ \\
\hline This paper & PROMETHEE II & $\begin{array}{l}\text { Arithmetic mean, } \\
\text { mean of discounted } \\
\text { net flows }\end{array}$ & $\begin{array}{l}\text { Scenarios (without } \\
\text { probabilities) }\end{array}$ & $\begin{array}{l}\text { Static of } \\
\text { dynamic }\end{array}$ & $\begin{array}{l}\text { Modeled } \\
\text { explicitly }\end{array}$ & $\begin{array}{l}\text { Sensitivity analysis } \\
\text { of discount factors }\end{array}$ \\
\hline
\end{tabular}

For the review, we followed processes described by [58,59]: (1) a literature search combining multi-period and multi-criteria in the databases ScienceDirect and Business Source Complete via EBSCOhost; (2) filtering out approaches that do not fit the MADM paradigm; and (3) successive forward and reverse searches. We discarded MP MADM approaches that model the multi-period nature of the decision problem with feedback between periods, which means that the decision table of one specific period is calculated based on some information of the previous periods, e.g., [60,61]. In these approaches, the multi-period nature of the decision problem is broken down into multiple successive single-period problems, which do not require a MP MADM approach. In [47], a model is developed that 
allow for the investigation of the convergence of criteria weights in MP group decisionmaking settings. Although temporal aggregation of performance scores and uncertainties are not addressed in this model, it allows for the definition of criteria weights that vary over time and converge in a group decision-making process. In [48], a general decomposition approach is developed for multi-criteria decision trees that can be used for decision making under uncertainty and explicitly considers path dependencies. We adopt the definition used in [51], where path dependency refers to the concept that choosing an alternative in one period may restrict the choice of alternatives in future periods. Because a decision tree is a technique that requires the definition of probabilities for scenarios, decision trees cannot be applied in the case of deep uncertainty, which is associated with decision problems from long-term energy systems planning. In consecutive publications building upon one another, [49-52] describe an MP MADM approach based on single synthesizing criterion approaches, such as MAUT, SMART, TOPSIS, MACBETH, or AHP, and apply it to case studies from sustainable forest management. Their MP MADM approach consists of five steps: (1) problem structuring; (2) uncertainty scenario definition; (3) (multiple SP) multi-criteria aggregations, based on criteria weights; (4) temporal aggregation, based on confidence levels of periods; (5) uncertainty aggregation, based on probabilities of scenarios. While criteria weights are assumed to be constant over time, confidence levels associated with periods need to be elicited from decision makers and can change in the future. In [53], a generic MP multi-criteria approach is developed, which acknowledges multiple periods and uncertainties. However, the specific methods for MP aggregation and uncertainty consideration are not described. In [54], an MP approach based on PROMETHEE II [25] is developed, which also includes multiple SP aggregations and a MP aggregation, and it is applied to the evaluations of the Human Development Index for emerging economies and the assessment of football players. Their MP approach features constant criteria weights, and allows confidence levels to be assigned to periods, which are assumed to be decreasing over time, and allows the preference thresholds of PROMETHEE-specific preference functions to be varied over time. However, this approach neither considers scenarios nor uncertainties in general. In [55], an MP PROMETHEE approach is developed, based on PROMETHEE I [25], where parameter uncertainties related to the performance scores are modeled with Monte Carlo simulations, so that a greater number of scenarios can be investigated. The internal consistency [62] of said scenarios, however, cannot be guaranteed. The MP aggregation is based on confidence levels assigned to the periods. This method is also applied to a case study in sustainable forest management. Both [56] and [57] describe similar MP PROMETHEE approaches, based on PROMETHEE II. The process is similar to the first four steps described in [51], and consists of: (1) MP problem formulation; (2) assessment of alternatives in each period; and (3) MP aggregation of assessments and sensitivity analysis. In the problem-structuring phase, path dependencies can be considered. Criteria weights can vary over time. PROMETHEE-specific thresholds for each period can be elicited from decision makers or calculated based on the performance scores. Afterwards, a single threshold is chosen for the whole planning horizon. Different variants for MP aggregations (with or without specifying confidence levels) are proposed, combining (weighted or arithmetic) averages with the net present value [63]. Scenarios for external uncertainties are not considered, but are pointed out as necessary extension.

In this paper, we mainly base the developed methodology upon [56], which is flexible regarding the specification of preference parameters, and allows for explicit consideration of path dependencies. The PROMETHEE approach is suitable for evaluating (future) energy systems regarding their sustainability, as it is easy to use and performance scores are only partially compensated $[64,65]$, which is desired in sustainability evaluations [66]. For example, it has already been applied to the evaluation of bioenergy pathways $[56,65-68]$ and energy systems in general [8,10,69-71]. We extend the approach described in [56] in such a way that the approach is suitable for MP evaluations in the context of deep uncertainty, by allowing the definition and evaluation of alternatives in different scenarios (MP-PROMETHEE-S). 


\section{MP MADM Approach under Deep Uncertainty}

Generally, MADM methods provide decision support to one or more decision makers in choosing an alternative (e.g., options for energy supply systems), based on the explicit consideration of multiple, conflicting criteria (e.g., investment or emissions) [29]. MADM can be structured into three phases: (1) problem structuring; (2) evaluation of options; and (3) reviewing the decision structure [29,72]. We first describe the standard notation of PROMETHEE. After that, we describe the extension to the MP case with scenarios (MP-PROMETHEE-S), based on [56].

\subsection{Description of PROMETHEE}

The preference ranking organization method for enrichment evaluations (PROMETHEE) is an outranking method that was largely developed by J.-P. Brans and is described in [25,73]. The pairwise comparison between a finite set of alternatives $a_{j} \in A=\left\{a_{1}, a_{2}, \ldots, a_{m}\right\}$ is conducted based on the performance scores $c_{i}\left(a_{j}\right):=x_{i j}$ for multiple criteria $c_{i} \in C=$ $\left\{c_{1}, c_{2}, \ldots, c_{n}\right\}$. In the first step, differences $d_{i}\left(a_{j}, a_{k}\right)=x_{i j}-x_{i k}$ between the performance scores of each criterion are calculated. Regarding these differences, decision makers can express their intra-criteria preferences through six different generic preference functions $P_{i}$. In these preference functions, preference parameters can be set:

- The indifference threshold $q_{i}$ defines the largest $d_{i}\left(a_{j}, a_{k}\right)$ that is considered negligible for the decision maker.

- The preference threshold $p_{i}$ defines the minimal $d_{i}\left(a_{j}, a_{k}\right)$ that is required for a strict preference on a criterion.

- The reversal point $\sigma_{i}$ represents the inflection point of the preference function (Type VI) and is derived from the normal distribution.

Based on the preference functions, outranking relations between two alternatives on each criterion are defined as $\pi_{i}\left(a_{j}, a_{k}\right)=P_{i}\left[d_{i}\left(a_{j}, a_{k}\right)\right]$. Decision makers can express their inter-criteria preferences with criteria weights $w_{i} \in W=\left\{w_{1}, w_{2}, \ldots, w_{n}\right\}$, with $\sum_{i=1}^{n} w_{i}=1$, which represents the relative importance of criteria in relation to others. By using these weights to aggregate the outranking relations, a preference matrix is calculated:

$$
\pi\left(a_{j}, a_{k}\right)=\sum_{i=1}^{n} w_{i} \cdot \pi_{i}\left(a_{j}, a_{k}\right)
$$

The preference matrix has the following properties:

$$
\left\{\begin{array}{c}
0 \leq \pi\left(a_{j}, a_{k}\right) \leq 1 \quad \forall j, k \in\{1, \ldots, n\} \\
0 \leq \pi\left(a_{j}, a_{k}\right)+\pi\left(a_{k}, a_{j}\right) \leq 1 \quad \forall j, k \in\{1, \ldots, n\} \\
\pi\left(a_{j}, a_{j}\right)=0 \quad \forall j \in\{1, \ldots, n\}
\end{array}\right.
$$

Finally, aggregated preference indices are calculated. Each alternative $a_{j}$ is facing $(m-1)$ other alternatives in $A$. Based on this, two outranking flows are defined. They represent the degrees to which $a_{j}$ is preferred over all other alternatives $a \in A \backslash a_{j}$ Equation (3), and all other alternatives $a \in A \backslash a_{j}$ are preferred over $a_{j}$ Equation (4).

$$
\begin{aligned}
& \text { Positive outranking flow : } \phi^{+}\left(a_{j}\right)=\frac{1}{m-1} \sum_{a \in A} \pi\left(a_{j}, a\right) \\
& \text { Negative outranking flow : } \phi^{-}\left(a_{j}\right)=\frac{1}{m-1} \sum_{a \in A} \pi\left(a, a_{j}\right)
\end{aligned}
$$

PROMETHEE I provides a partial ranking of alternatives, which is obtained from the positive and negative outranking flows. By aggregating these to the net outranking flow with $\phi^{-n e t}\left(a_{j}\right)=\phi^{+}\left(a_{j}\right)-\phi^{-}\left(a_{j}\right)$ in PROMETHEE II, a total ranking of alternatives is possible. 


\subsection{Extension of PROMETHEE to the MP Case with Scenarios (MP-PROMETHEE-S)}

For the MP extension of PROMETHEE under different scenarios (MP-PROMETHEES), a set of periods $t \in\{1, \ldots, T\}$, in which the alternatives are quantitatively modeled and evaluated, and a set of scenarios $s \in\{1, \ldots, S\}$ are introduced. Accordingly, there is a set of alternatives $a_{j, t} \in A_{t}$, with $j$ the number of alternatives in a period $t$. Alternative $a_{1,0}$ represents the status quo, which does not need to be evaluated. The number of alternatives can vary across periods, i.e., the number of alternatives in the first period could be smaller than the number of alternatives in the second period. We assume that in practice, the set of evaluation criteria $c_{i}$ remains constant across periods. However, criteria weights $w_{i, t, s} \in W_{t, s}$ may vary across periods $t$ and scenarios $s([37,74-76]$ agree that criteria weights should also depend on scenarios), which implies that a criterion could be neglected in a period or scenario by setting its weight $w_{i, t, s}=0$. We assume that the assignment of preference functions to criteria remains constant across periods and scenarios. The performance of alternatives in different periods and scenarios regarding the criteria is denoted with performance scores $x_{i j, t, s}$. Across multiple periods, alternatives are combined into transition paths $\Psi=\left(a_{j, 1}, a_{j, 2}, \ldots, a_{j, T}\right)$, encompassing sequences of alternatives over all periods $t$. Having introduced the extended notation, we now describe the process of MP-PROMETHEE-S, which is structured into three steps. The first step corresponds to the problem-structuring phase of a generic MADM process, while the second and third steps correspond to the evaluation of options phase.

Step 1: MP problem formulation with scenarios

The decision problem is formulated and structured with multiple periods. In contrast to an SP evaluation, different alternatives $a_{j, t}$ are defined for each period $t$. After that, possible paths $\Psi$ are defined, according to an analysis of path dependencies (for example, from energy systems planning, see, e.g., $[77,78])$. In addition to alternatives and paths, scenarios are defined, with corresponding quantitative assumptions for each period $t$. A suitable approach for the definition of scenarios that also fits to MADM approaches in the context of energy systems planning is described in [10]. Finally, performance scores $x_{i j, t, s}$ can be calculated with the help of one or multiple system model(s), so that decision tables can be compiled for each scenario $s$.

Step 2: SP evaluations of alternatives in each period and scenario

The alternatives are evaluated separately for each period with PROMETHEE II, resulting in $\phi^{n e t}\left(a_{j, t, s}\right)$ for each period $t$ and scenario $s$. In this step, criteria weights can be elicited according to stakeholders' preferences, or set equal and analyzed with a sensitivity analysis afterwards. The preference thresholds are dependent on the analyzed alternatives. In $S P$ evaluations, following [70], preference thresholds $p_{i}$ and indifference thresholds $q_{i}$ for each scenario $s$ can be estimated as percentages of $\max \left(x_{i j, t, s}\right)-\min \left(x_{i j, t, s}\right)$ for each criterion $i$, in each period $t$. For example, the indifference thresholds $q_{i}$ can be estimated as $5-15 \%$ and the preference thresholds $p_{i}$ as $10-30 \%$ of this difference. In MP evaluations, to account for possible outliers or large deviations of the performance scores in-between different periods, thresholds can be calculated as $\max \left[\max \left(x_{\mathrm{ij}, \mathrm{t}, \mathrm{s}}\right)-\min \left(x_{i j, t, \mathrm{~s}}\right)\right]$. Preference thresholds are not aggregated over scenarios.

Step 3: MP aggregation of evaluations, sensitivity analysis, and evaluation of scenarios

The $\phi^{\text {net }}$ of all alternatives $a \in \Psi$ for a given path $\Psi$ are aggregated. In [56], four different variants for MP aggregation are proposed. Of those four variants, we select two because of their ease of use. Note that both variants lead to normalized path evaluations $\phi^{\text {net }}(\Psi) \in[-1,1]$, which can be interpreted in the same way as the net flows related to alternatives $\phi^{\text {net }}\left(a_{j, t, s}\right)$ : higher $\phi^{\text {net }}(\Psi)$ represent better evaluations for path $\Psi$.

Variant 1 is the arithmetic mean, which implies that all alternatives included in a transition path $\Psi$ contribute equally to its evaluation.

$$
\phi_{\text {average }}^{\text {net }}(\Psi)=\frac{1}{T} \cdot \sum_{a \in \Psi} \phi^{n e t}(a)
$$


Variant 2 is the average of discounted $\phi^{\text {net }}$ flows, where $r$ is a discount factor. This may be used in decision problems with long planning horizons.

$$
\phi_{\text {averageDis }}^{n e t}(\Psi, \mathrm{r})=\frac{1}{T} \cdot \sum_{a \in \Psi} \frac{\phi^{n e t}(a)}{(1+r)^{t}}
$$

In finance, the net present value incorporates the time value of money, which basically states that present cash flows are preferred to future cash flows. The method has also been applied to non-financial values [79-81]. We assume a similar reasoning regarding PROMETHEE net flows: Assuming a fixed planning horizon, positive evaluations (i.e., higher $\phi^{\text {net }}$ values) occurring in earlier periods will prevail for a longer time. Additionally, this considers that performance scores calculated for alternatives of later periods-and their evaluations-are more uncertain than those of earlier periods. An open question, however, is what discount factors are suitable. In [82], it is argued that the lowest possible, nonnegative interest rates should be chosen for the evaluation of inter-generational decisions with long-term consequences. However, for exceedingly small discount rates, both variants basically lead to the same path evaluations:

$$
\lim _{r \rightarrow 0}\left(\frac{1}{T} \cdot \sum_{a \in \Psi} \frac{\phi^{n e t}(a)}{(1+r)^{t}}\right)=\frac{1}{T} \cdot \sum_{a \in \Psi} \phi^{n e t}(a)
$$

A sensitivity analysis can be applied to gain further insights into the decision problem. Regarding SP evaluations (Step 2), criteria weights and indifference/preference thresholds can be varied. Regarding MP aggregation with variant 2, $r$ can be varied to analyze the impact of different degrees of uncertainty and confidence associated with future evaluations.

One issue in integrating the use of scenarios with MADM approaches is how (or even whether) to compare and aggregate results from different scenarios [33,34,83]. For example, [42,76] argue that aggregation should not use scenario probabilities (because the set of scenarios does not constitute a complete probability space), nor likelihoods (because scenarios are incomplete descriptions, and they cannot in general be expected to represent the same dimensions in probability space), contrary to some MP MADM approaches described in Section 2. We therefore choose to assess the stability of evaluations across scenarios by directly presenting information about the range of performances across scenarios.

\section{Case Study: Planning the Local Energy Transition in Jühnde}

In this case study, we revisit the case of planning the transition of the power generation system in Jühnde, Germany, over multiple periods, as described in [56] (for further information on the bioenergy town Jühnde, see $[68,84,85])$. In addition to the MP multicriteria evaluation described in the original case, we also develop a set of scenarios for modelling varying assumptions for external conditions, and apply MP-PROMETHEE-S to this decision problem. The objective of the case study is to investigate the value added through the investigation of several scenarios.

Step 1: MP problem formulation with scenarios

Analogous to the original case study, the decision problem is to identify a sustainable investment portfolio specified by capacity expansions of different renewable energy technologies (drawing on biogas, wind, and solar energy) in the bioenergy town Jühnde in the periods 2005, 2010, 2015, and 2020. Power that cannot be provided in the town but is needed to satisfy the demand is provided externally (in each year, the power supply totals $8021 \mathrm{MWh}$, corresponding to the demand before the renewable capacity expansion). The stakeholders of the decision problem are the inhabitants of the town. However, to simplify the decision-making process and because we focus on the consideration of multiple periods and uncertainties, generic $[18,47,64,86]$ or PROMETHEE-specific $[87,88]$ group decision-making frameworks are not employed. We also adopt the same transition paths $\Psi$, which are described in detail in Table 2 . 
Table 2. Power supply of renewable energy technologies in different expansion paths in MWh. Added capacity is depicted in italics.

\begin{tabular}{|c|c|c|c|c|c|}
\hline & Power Supply & 2005 & 2010 & 2015 & 2020 \\
\hline \multirow{3}{*}{$\Psi 1$} & Biogas power plant & $\begin{array}{c}4816.68 \\
(+4816.68)\end{array}$ & $\begin{array}{c}6811.31 \\
(+1994.63)\end{array}$ & 6811.31 & 6811.31 \\
\hline & PV systems & $\begin{array}{c}95.83 \\
(+95.83)\end{array}$ & $\begin{array}{c}388.70 \\
(+292.87)\end{array}$ & $\begin{array}{c}706.31 \\
(+317.61)\end{array}$ & 706.31 \\
\hline & Wind power plant & - & - & - & - \\
\hline \multirow{3}{*}{$\Psi 2$} & Biogas power plant & $\begin{array}{c}4816.68 \\
(+4816.68)\end{array}$ & 4816.68 & 4816.68 & 4816.68 \\
\hline & PV systems & - & - & $\begin{array}{c}2700.94 \\
(+2700.94)\end{array}$ & 2700.94 \\
\hline & Wind power plant & - & - & - & - \\
\hline \multirow{3}{*}{$\Psi 3$} & Biogas power plant & $\begin{array}{c}4816.68 \\
(+4816.68)\end{array}$ & 4816.68 & 4816.68 & 4816.68 \\
\hline & PV systems & - & - & - & - \\
\hline & Wind power plant & - & - & $\begin{array}{c}2700.94 \\
(+2700.94)\end{array}$ & 2700.94 \\
\hline \multirow{3}{*}{$\Psi 4$} & Biogas power plant & - & - & - & - \\
\hline & PV systems & $\begin{array}{c}95.83 \\
(+95.83)\end{array}$ & 95.83 & $\begin{array}{c}1541.66 \\
(+1445.83)\end{array}$ & $\begin{array}{c}2700.94 \\
(+1159.28)\end{array}$ \\
\hline & Wind power plant & $\begin{array}{c}4816.68 \\
(+4816.68)\end{array}$ & 4816.68 & 4816.68 & 4816.68 \\
\hline
\end{tabular}

$\Psi 1$ Baseline represents the real-world development of renewable energy expansion in Jühnde, with two investments in a biogas power plant and PV systems. 22 Biomass and Photovoltaic represents the original investment in a bioenergy power plant in 2005 and further extension with rooftop PV systems in 2015. 43 Biomass and Wind also represents the original investment in a bioenergy power plant, but is complemented with wind energy in 2015. In $\Psi 4$ Wind and PV, the bioenergy plant is substituted by wind energy plants and complemented with rooftop PV systems in 2015 and 2020.

To facilitate comparability between the original approach described in [56] and our advanced MP MADM approach, the transition paths are evaluated regarding four criteria: levelized costs of electricity (LCOE), land use, $\mathrm{CO}_{2}$ emissions, and the degree of selfsufficiency of the town. For calculating the transition paths' performance scores in terms of these criteria, the same assumptions and energy system model were used as in the original case study described in [56]. In particular, we used [89-92] to quantify the levelized costs of electricity, [93] to quantify the land use, [94] to quantify $\mathrm{CO}_{2}$ emissions, and [95,96] to quantify the self-sufficiency of the town.

For modelling external uncertainties, we developed a set of scenarios for the power system of Jühnde, which was methodologically aided by a cross-impact balance (CIB) analysis and supported by its corresponding software tool [97-99]. Three descriptors with major influence on the development of Jühnde's power system were identified:

1. Technical progress (power supply): This key factor represents the technical progress in terms of efficiency gains of already readily available power generation technologies.

2. Governmental support: This represents the governmental support of power generation technologies, e.g., in terms of subsidies or R\&D, as well as fostering awareness for energy efficiency in the public.

3. Public contribution: This represents the behavior of the public in terms of acceptance of energy-efficient electrical appliances. 
For each key factor, three variants (historic, increased, and decreased) were developed, resulting in a total of nine variants. In the cross-impact matrix depicted in Table 3, the authors evaluated the pair-wise consistency of projections on a seven-point scale $(-3$ : strongly restricting influence, $\ldots,+3$ : strongly promoting influence). A subsequent cluster analysis of this matrix yielded four consistent scenarios (S1, S2, S3, S4). For investigating potential effects of the current COVID-19 pandemic $[100,101]$, we also included S5 with $20 \%$ lower energy demand in 2020. In Table 4, the qualitative scenarios are shown.

Table 3. Cross-impact matrix for the case study. A: technical progress; B: political support; C: public contribution; hist: historical development; +: increased; -: decreased.

\begin{tabular}{cccccccccc}
\hline & A1: Hist & A2: + & A3: - & B1: Hist & B2: + & B3: - & C1: Hist & C2: + & C3: - \\
\hline A1: hist & & & & 2 & 1 & 1 & 2 & 1 & 1 \\
\hline A2: + & & & & -1 & 1 & -1 & 1 & 1 & 1 \\
\hline A3: - & & & & 1 & 0 & 1 & 1 & 1 & 1 \\
\hline B1: hist & 3 & 2 & -2 & & & & 3 & 1 & 1 \\
\hline B2: + & -1 & 3 & -3 & & & & -1 & 3 & -2 \\
\hline B3: - & 1 & -1 & 3 & & & & -1 & -2 & 3 \\
\hline C1: hist & 0 & 0 & 0 & 1 & 0 & 0 & & & \\
\hline C2: + & 0 & 0 & 0 & 0 & -1 & 0 & & & \\
\hline C3: - & 0 & 0 & 0 & 0 & 0 & -1 & & & \\
\hline
\end{tabular}

Table 4. Qualitative scenarios regarding the power generation system in Jühnde.

\begin{tabular}{cccccc}
\hline Scenario & $\begin{array}{c}\text { S1: } \\
\text { Reference }\end{array}$ & $\begin{array}{c}\text { S2: Best } \\
\text { Case }\end{array}$ & $\begin{array}{c}\text { S3: Worst } \\
\text { Case }\end{array}$ & $\begin{array}{c}\text { S4: Efficient } \\
\text { Power } \\
\text { Generation }\end{array}$ & $\begin{array}{c}\text { S5: Lower } \\
\text { Energy } \\
\text { Demand }\end{array}$ \\
\hline $\begin{array}{c}\text { A: Technical progress } \\
\text { B: Political support }\end{array}$ & Historic & Increased & Decreased & Increased & Historic \\
C: Public contribution & Historic & Increased & Decreased & Historic & Historic \\
\hline
\end{tabular}

To transform the qualitative scenarios into quantitative assumptions for the energy system model [3,102], we adopt the same assumptions used by [56] for S1 and alter the assumptions for S2-S5. The scenarios' assumptions are described in Table 5. Note that potential rebound effects due to the availability of more efficient electrical appliances [103] are neglected in quantifying the energy demand over time. With the help of the energy system model, performance scores $x_{i j, t, s}$ are computed and compiled in a decision table, which is depicted in Table 6 . In scenarios with decreasing energy demand, negative $\mathrm{CO}_{2}$ emissions occur, because the power production exceeds the demand in Jühnde and power is fed into the grid. Up to $t=2010, \Psi 2$ and $\Psi 3$ have the same performance scores for all criteria in all scenarios, because the renewable capacity expansion in these paths is the same up to this point. 
Table 5. Quantitative scenario assumptions.

\begin{tabular}{|c|c|c|c|c|c|c|c|c|c|c|}
\hline \multirow[b]{2}{*}{ Scenarios } & \multirow{2}{*}{\multicolumn{2}{|c|}{$\begin{array}{c}\begin{array}{c}\text { Emission } \\
\text { Factor in } \\
\mathrm{CO}_{2} \cdot(k W h)^{-1}\end{array} \\
\begin{array}{c}\text { Power from } \\
\text { grid }\end{array}\end{array}$}} & \multicolumn{3}{|c|}{$\begin{array}{l}\text { Agricultural Land Use in } \\
\text { Jühnde in } m^{2} \cdot(M W h)^{-1} y^{-1}\end{array}$} & \multicolumn{4}{|c|}{ Levelized Cost of Electricity in $€ \cdot(k W h)^{-1}$} & \multirow{2}{*}{$\begin{array}{c}\text { Electricity } \\
\text { Demand in } \\
M W h \cdot y^{-1} \\
-\end{array}$} \\
\hline & & & Bioenergy & $\begin{array}{l}\text { Ground- } \\
\text { mounted } \\
\text { PV }\end{array}$ & $\begin{array}{l}\text { Wind } \\
\text { energy }\end{array}$ & $\begin{array}{l}\text { Power } \\
\text { from grid }\end{array}$ & Bioenergy & $\begin{array}{l}\text { Rooftop/ground- } \\
\text { mounted } \\
\text { PV }\end{array}$ & $\begin{array}{l}\text { Wind } \\
\text { energy }\end{array}$ & \\
\hline \multirow{4}{*}{$\begin{array}{l}\text { S1: Reference } \\
\text { Scenario }\end{array}$} & 2005 & 586 & 980 & 30 & 60 & 0.11 & 0.10 & 0.54 & 0.09 & 8021 \\
\hline & 2010 & 567 & 980 & 30 & 60 & 0.14 & 0.11 & 0.35 & 0.08 & 8021 \\
\hline & 2015 & 511 & 980 & 30 & 60 & 0.13 & 0.11 & 0.21 & 0.08 & 8021 \\
\hline & 2020 & 471 & 980 & 30 & 60 & 0.14 & 0.10 & 0.14 & 0.07 & 8021 \\
\hline \multirow{4}{*}{ S2: Best case } & 2005 & 527.76 & 882.00 & 27.00 & 54.00 & 0.10 & 0.09 & 0.48 & 0.08 & 7860.58 \\
\hline & 2010 & 474.98 & 793.80 & 24.30 & 48.60 & 0.09 & 0.08 & 0.32 & 0.07 & 7703.37 \\
\hline & 2015 & 427.49 & 741.42 & 21.87 & 43.74 & 0.08 & 0.07 & 0.19 & 0.06 & 7549.30 \\
\hline & 2020 & 384.74 & 642.98 & 19.68 & 39.37 & 0.07 & 0.07 & 0.12 & 0.06 & 7398.32 \\
\hline \multirow{4}{*}{$\begin{array}{l}\text { S3: Worst } \\
\text { case }\end{array}$} & 2005 & 645.04 & 1078.00 & 33.00 & 66.00 & 0.12 & 0.11 & 0.59 & 0.10 & 8181.42 \\
\hline & 2010 & 709.54 & 1185.80 & 36.30 & 72.60 & 0.14 & 0.12 & 0.39 & 0.11 & 8345.05 \\
\hline & 2015 & 780.50 & 1304.38 & 39.93 & 79.86 & 0.15 & 0.13 & 0.23 & 0.12 & 8511.95 \\
\hline & 2020 & 858.55 & 1434.82 & 43.92 & 87.85 & 0.17 & 0.15 & 0.15 & 0.13 & 8682.19 \\
\hline \multirow{4}{*}{$\begin{array}{l}\text { S4: Efficient } \\
\text { power } \\
\text { generation }\end{array}$} & 2005 & 547.67 & 960.4 & 29.4 & 58.8 & 0.11 & 0.10 & 0.54 & 0.09 & 8021 \\
\hline & 2010 & 555.46 & 941.19 & 28.81 & 57.62 & 0.14 & 0.11 & 0.35 & 0.08 & 8021 \\
\hline & 2015 & 500.49 & 922.37 & 28.24 & 56.47 & 0.13 & 0.11 & 0.21 & 0.08 & 8021 \\
\hline & 2020 & 462.01 & 903.92 & 27.67 & 55.34 & 0.14 & 0.10 & 0.14 & 0.07 & 8021 \\
\hline \multirow{4}{*}{$\begin{array}{l}\text { S5: Low } \\
\text { energy } \\
\text { demand in } \\
2020\end{array}$} & 2005 & 586 & 980 & 30 & 60 & 0.11 & 0.10 & 0.54 & 0.09 & 8021 \\
\hline & 2010 & 567 & 980 & 30 & 60 & 0.14 & 0.11 & 0.35 & 0.08 & 8021 \\
\hline & 2015 & 511 & 980 & 30 & 60 & 0.13 & 0.11 & 0.21 & 0.08 & 8021 \\
\hline & 2020 & 471 & 980 & 30 & 60 & 0.14 & 0.10 & 0.14 & 0.07 & 6416.8 \\
\hline
\end{tabular}

Table 6. Decision table. LCOE in cent/kWh; land use in ha/a; $\mathrm{CO}_{2}: \mathrm{CO}_{2}$ emissions in t/a; SS: self-sufficiency in \%.

\begin{tabular}{|c|c|c|c|c|c|c|c|c|c|c|c|c|c|c|c|c|c|}
\hline \multirow{2}{*}{\multicolumn{2}{|c|}{ Year }} & \multicolumn{4}{|c|}{$\Psi 1$} & \multicolumn{4}{|c|}{$\Psi 2$} & \multicolumn{4}{|c|}{$\Psi 3$} & \multicolumn{4}{|c|}{$\Psi 4$} \\
\hline & & LCOE & $\begin{array}{l}\text { Land } \\
\text { Use }\end{array}$ & $\mathrm{CO}_{2}$ & SS & LCOE & $\begin{array}{l}\text { Land } \\
\text { Use }\end{array}$ & $\mathrm{CO}_{2}$ & SS & LCOE & $\begin{array}{l}\text { Land } \\
\text { Use }\end{array}$ & $\mathrm{CO}_{2}$ & SS & LCOE & $\begin{array}{l}\text { Land } \\
\text { Use }\end{array}$ & $\mathrm{CO}_{2}$ & SS \\
\hline \multirow{4}{*}{ S1 } & 2005 & 11.01 & 472.03 & 1823 & 61.25 & 10.51 & 472.03 & 1879 & 60.05 & 10.51 & 472.03 & 1879 & 60.05 & 10.29 & 28.90 & 1823 & 47.63 \\
\hline & 2010 & 12.01 & 667.57 & 465 & 89.77 & 11.61 & 472.03 & 1816 & 60.05 & 11.61 & 472.03 & 1816 & 60.05 & 11.36 & 28.90 & 1762 & 47.63 \\
\hline & 2015 & 12.24 & 667.57 & 257 & 93.38 & 13.97 & 472.03 & 257 & 83.95 & 9.42 & 488.24 & 257 & 87.83 & 12.47 & 28.90 & 849 & 60.75 \\
\hline & 2020 & 12.28 & 667.57 & 237 & 93.38 & 14.01 & 472.03 & 237 & 83.95 & 9.47 & 488.24 & 237 & 87.83 & 12.59 & 28.90 & 237 & 65.41 \\
\hline \multirow{4}{*}{ S2 } & 2005 & 9.91 & 424.83 & 1556 & 62.50 & 9.44 & 424.83 & 1606 & 61.28 & 9.44 & 424.83 & 1606 & 61.28 & 9.24 & 26.01 & 1556 & 48.20 \\
\hline & 2010 & 10.13 & 583.22 & 239 & 93.47 & 9.05 & 424.83 & 1371 & 62.53 & 9.05 & 424.83 & 1,371 & 62.53 & 8.86 & 26.01 & 1326 & 48.77 \\
\hline & 2015 & 10.57 & 583.22 & 14 & 95.06 & 12.60 & 424.83 & 14 & 86.08 & 8.07 & 436.64 & 14 & 90.18 & 10.61 & 26.01 & 509 & 62.62 \\
\hline & 2020 & 10.63 & 583.22 & -46 & 95.54 & 12.71 & 424.83 & -46 & 86.78 & 8.08 & 436.64 & -46 & 90.92 & 11.32 & 26.01 & -46 & 67.60 \\
\hline \multirow{4}{*}{ S3 } & 2005 & 12.12 & 519.24 & 2109 & 60.04 & 11.58 & 519.24 & 2170 & 58.87 & 11.58 & 519.24 & 2170 & 58.87 & 11.34 & 31.79 & 2109 & 47.07 \\
\hline & 2010 & 13.16 & 755.84 & 812 & 86.27 & 12.12 & 519.24 & 2504 & 57.72 & 12.12 & 519.24 & 2504 & 57.72 & 11.87 & 31.79 & 2436 & 46.51 \\
\hline & 2015 & 13.69 & 755.84 & 776 & 88.31 & 15.38 & 519.24 & 776 & 81.80 & 11.69 & 540.81 & 776 & 85.32 & 13.90 & 31.79 & 1681 & 58.87 \\
\hline & 2020 & 13.91 & 755.84 & 1000 & 86.58 & 15.57 & 519.24 & 1000 & 81.07 & 11.96 & 540.81 & 1000 & 84.45 & 14.13 & 31.79 & 1000 & 63.18 \\
\hline \multirow{4}{*}{ S4 } & 2005 & 11.01 & 462.59 & 1786 & 61.25 & 10.51 & 462.59 & 1841 & 60.05 & 10.51 & 462.59 & 1841 & 60.05 & 10.29 & 28.32 & 1786 & 47.63 \\
\hline & 2010 & 12.01 & 650.39 & 456 & 89.77 & 11.61 & 462.59 & 1780 & 60.05 & 11.61 & 462.59 & 1780 & 60.05 & 11.36 & 28.32 & 1727 & 47.63 \\
\hline & 2015 & 12.24 & 650.39 & 252 & 93.38 & 13.97 & 462.59 & 252 & 83.95 & 9.42 & 477.85 & 252 & 87.83 & 12.47 & 28.32 & 832 & 60.75 \\
\hline & 2020 & 12.28 & 650.39 & 233 & 93.38 & 14.01 & 462.59 & 233 & 83.95 & 9.47 & 477.85 & 233 & 87.83 & 12.59 & 28.32 & 233 & 65.41 \\
\hline \multirow{4}{*}{ S5 } & 2005 & 11.01 & 472.03 & 1823 & 61.25 & 10.51 & 472.03 & 1879 & 60.05 & 10.51 & 472.03 & 1879 & 60.05 & 10.29 & 28.90 & 1823 & 47.63 \\
\hline & 2010 & 12.01 & 667.57 & 465 & 89.77 & 11.61 & 472.03 & 1816 & 60.05 & 11.61 & 472.03 & 1816 & 60.05 & 11.36 & 28.90 & 1762 & 47.63 \\
\hline & 2015 & 12.24 & 667.57 & 257 & 93.38 & 13.97 & 472.03 & 257 & 83.95 & 9.42 & 488.24 & 257 & 87.83 & 12.47 & 28.90 & 849 & 60.75 \\
\hline & 2020 & 11.89 & 667.57 & -519 & 97.96 & 14.06 & 472.03 & -519 & 91.46 & 8.38 & 488.24 & -519 & 95.25 & 12.28 & 28.90 & -519 & 71.21 \\
\hline
\end{tabular}


Step 2: SP evaluations of alternatives in each period and scenario

For the SP evaluation of alternatives with PROMETHEE II, we selected the V-shape criterion (preference function type III) [25]. We estimated preference thresholds $p_{i, s}$ for each criterion $i$ and scenario $s$ as $\max \left[0.2 \cdot \max \left(x_{i j, t, s}\right)-\min \left(x_{i j, t, s}\right)\right]$. Table 7 summarizes inter- and intra-criteria preferences. Due the re-visiting the case, and to reduce complexity, we assume that criteria weights remain constant across all periods and scenarios. Later, the effects of changes in criteria weights are analyzed in a sensitivity analysis.

Table 7. Overview on criteria and PROMETHEE thresholds.

\begin{tabular}{ccccccccc}
\hline Criterion & Unit & Type & Weight & $p_{i, 1}$ & $p_{i, 2}$ & $p_{i, 3}$ & $p_{i, 4}$ & $p_{i, 5}$ \\
\hline LCOE & cent/kWh & Min & 0.25 & 0.91 & 2.19 & 4.02 & 0.91 & 1.14 \\
\hline Land use & ha/a & Min & 0.25 & 127.73 & 111.44 & 144.81 & 124.41 & 127.73 \\
\hline $\mathrm{CO}_{2}$ emissions & $\mathrm{t} / \mathrm{a}$ & Min & 0.25 & 270.20 & 226.40 & 338.20 & 264.80 & 270.20 \\
\hline Self-sufficiency & $\%$ & Max & 0.25 & 8.43 & 8.94 & 7.95 & 8.43 & 8.43 \\
\hline
\end{tabular}

Table 8 shows the results of the SP evaluations for all scenarios with PROMETHEE II. Additionally, the ranks of alternatives according to $\phi^{\text {net }}$ are provided from 1 to 4 . If multiple alternatives have the same $\phi^{\text {net }}$, their ranks are determined with the arithmetic mean. It can be observed that, in general, the alternatives' $\phi^{\text {net }}$ and ranks vary depending on the periods and scenarios. For example, in the periods $t=2010$ and $t=2015$, the alternatives' ranks vary, depending on the scenario. However, in $t=2005$ and $t=2020$, all the alternatives' ranks remain the same, regardless of scenario. Up to $t=2010, \Psi 2$ and $\Psi 3$ have the same evaluations and ranks (because of their similar capacity expansions and performance scores, as described above).

Table 8. Evaluation of alternatives in periods and scenarios.

\begin{tabular}{|c|c|c|c|c|c|c|c|c|c|}
\hline & & \multicolumn{2}{|c|}{$t=2005$} & \multicolumn{2}{|c|}{$t=2010$} & \multicolumn{2}{|c|}{$t=2015$} & \multicolumn{2}{|c|}{$t=2020$} \\
\hline & & $\phi^{n e t}\left(a_{j, 2005, s}\right)$ & Rank & $\left(a_{j, 2010, s}\right)$ & Rank & $\left(a_{j, 2015, s}\right)$ & Rank & $\left(a_{j, 2020, s}\right)$ & Rank \\
\hline \multirow{4}{*}{ S1 } & $\Psi 1$ & -0.099 & 4 & 0.117 & 1 & 0.076 & 2 & 0.000 & 2 \\
\hline & $\Psi 2$ & -0.021 & 2.5 & -0.086 & 3.5 & -0.194 & 3 & -0.278 & 4 \\
\hline & $\Psi 3$ & -0.021 & 2.5 & -0.086 & 3.5 & 0.390 & 1 & 0.306 & 1 \\
\hline & $\Psi 4$ & 0.141 & 1 & 0.055 & 2 & -0.271 & 4 & -0.028 & 3 \\
\hline \multirow{4}{*}{ S2 } & $\Psi 1$ & -0.085 & 4 & 0.000 & 2 & 0.049 & 2 & 0.020 & 2 \\
\hline & $\Psi 2$ & -0.024 & 2.5 & -0.034 & 3.5 & -0.196 & 3 & -0.278 & 4 \\
\hline & $\Psi 3$ & -0.024 & 2.5 & -0.034 & 3.5 & 0.401 & 1 & 0.320 & 1 \\
\hline & $\Psi 4$ & 0.133 & 1 & 0.067 & 1 & -0.254 & 4 & -0.062 & 3 \\
\hline \multirow{4}{*}{ S3 } & $\Psi 1$ & -0.151 & 4 & 0.000 & 2 & 0.040 & 2 & -0.062 & 3 \\
\hline & $\Psi 2$ & -0.008 & 2.5 & -0.045 & 3.5 & -0.176 & 3 & -0.247 & 4 \\
\hline & $\Psi 3$ & -0.008 & 2.5 & -0.045 & 3.5 & 0.410 & 1 & 0.334 & 1 \\
\hline & $\Psi 4$ & 0.168 & 1 & 0.090 & 1 & -0.274 & 4 & -0.025 & 2 \\
\hline \multirow{4}{*}{ S4 } & $\Psi 1$ & -0.099 & 4 & 0.117 & 1 & 0.076 & 2 & 0.000 & 2 \\
\hline & $\Psi 2$ & -0.021 & 2.5 & -0.086 & 3.5 & -0.195 & 3 & -0.278 & 4 \\
\hline & $\Psi 3$ & -0.021 & 2.5 & -0.086 & 3.5 & 0.390 & 1 & 0.307 & 1 \\
\hline & $\Psi 4$ & 0.141 & 1 & 0.055 & 2 & -0.271 & 4 & -0.028 & 3 \\
\hline \multirow{4}{*}{ S5 } & $\Psi 1$ & -0.068 & 4 & 0.144 & 1 & 0.072 & 2 & -0.047 & 3 \\
\hline & $\Psi 2$ & -0.026 & 2.5 & -0.089 & 3.5 & -0.194 & 3 & -0.258 & 4 \\
\hline & $\Psi 3$ & -0.026 & 2.5 & -0.089 & 3.5 & 0.390 & 1 & 0.333 & 1 \\
\hline & $\Psi 4$ & 0.120 & 1 & 0.034 & 2 & -0.267 & 4 & -0.029 & 2 \\
\hline
\end{tabular}


Step 3: MP aggregation of evaluations, sensitivity analysis, and evaluation of scenarios Figure 1 shows the MP evaluations $\phi^{n e t}(\Psi)$ in variants 1 and $2(r=1 \%, 5 \%$, and 10\%) across all scenarios in a box plot. The ranges depicted by the boxes correspond to the ranges of the paths' evaluations across different scenarios. Regardless of the chosen scenario, MP aggregation variant, and discount factor, $\Psi 3$ comes off best and $\Psi 2$ comes off worst. Higher discount factors improve the evaluation of $\Psi 4$ compared to $\Psi 1$. In a sensitivity analysis of the discount factor $r$, we investigated its effect on rank reversals within $r=[0 \% ; 10 \%]$ : In S1 and S4, $\Psi 4$ overtakes $\Psi 1$ at $r=3 \%$; in S2, their ranks switch at $r=6.6 \%$; in S3, and S5, there is no rank reversal.

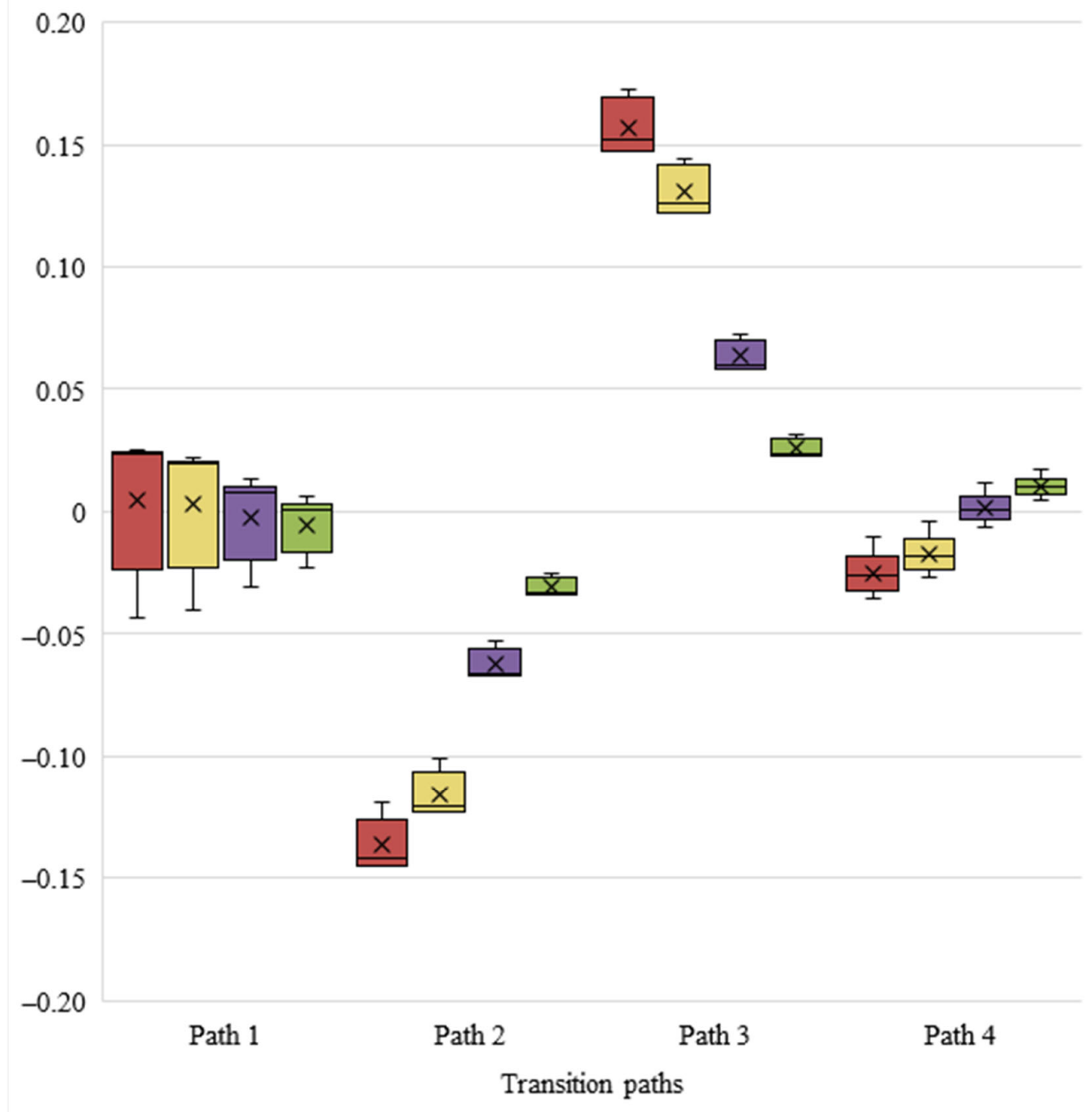

$\square$ Variant $1 \square$ Variant 2, r = 1\% $\square$ Variant 2, r = 5\% $\square$ Variant 2, r= $10 \%$

Figure 1. Results of the MP aggregation $\phi^{n e t}(\Psi)$, with variants 1 and $2(r=1 \%, 5 \%$, and $10 \%)$.

In further sensitivity analysis, we investigated the effects of criteria weights on the optimality of paths, based on a MP aggregation with variant 1 . To that end, the criteria weight of any single criterion is varied relative to all other criteria weights, i.e., if any weight $w_{i}$ is increased (or decreased), the weights of all other criteria $w \in W \backslash w_{i}$ are decreased (or increased) accordingly. To avoid setting weights arbitrarily, criteria weights are varied between $0 \%$ and $40 \%$, potentially neglecting a criterion or doubling the weight of any other single criterion. Table 9 shows the optimal paths, if the weight of any criterion is increased or decreased from $25 \%$, with the corresponding thresholds for the rank reversals. Except for $\Psi 2$, all paths are potentially optimal for some set of weights. In the given boundaries, 
varying the weight of $\mathrm{CO}_{2}$ emissions does not have an impact on the ranks of the paths. The smallest deviation from equal weights $(25 \%)$, which would be necessary for a rank reversal, is a $10.16 \%$ increase in the criteria weight of land use in S1. For the given decision problem, the scenarios broaden the range in which rank reversals occur, but the next-best path is always the same, regardless of scenario (provided that the optimal path does change at all). For example, if the weight of LCOE is decreased, $\Psi 1$ becomes the optimal path in each scenario.

Table 9. Sensitivity analysis: optimal paths with weight thresholds (in \%), based on the MP aggregation with variant 1 .

\begin{tabular}{ccccccccccc}
\hline & \multicolumn{2}{c}{ S1 } & \multicolumn{2}{c}{ S2 } & \multicolumn{2}{c}{ S3 } & \multicolumn{2}{c}{ S4 } & \multicolumn{2}{c}{ S5 } \\
\cline { 2 - 11 } & $w_{i} \uparrow$ & $w_{i} \downarrow$ & $w_{i} \uparrow$ & $w_{i} \downarrow$ & $w_{i} \uparrow$ & $w_{i} \downarrow$ & $w_{i} \uparrow$ & $w_{i} \downarrow$ & $w_{i} \uparrow$ & $w_{i} \downarrow$ \\
\hline \multirow{2}{*}{ LCOE } & $\Psi 3$ & $\Psi 1$ & $\Psi 3$ & $\Psi 1$ & $\Psi 3$ & $\Psi 1$ & $\Psi 3$ & $\Psi 1$ & $\Psi 3$ & $\Psi 1$ \\
& - & 10.85 & - & 8.02 & - & 4.25 & - & 10.84 & - & 8.91 \\
\hline \multirow{2}{*}{ Land use } & $\Psi 4$ & $\Psi 1$ & $\Psi 4$ & $\Psi 1$ & $\Psi 4$ & $\Psi 3$ & $\Psi 4$ & $\Psi 1$ & $\Psi 4$ & $\Psi 1$ \\
& 35.16 & 9.66 & 36.27 & 2.36 & 35.63 & - & 35.18 & 9.66 & 35.89 & 9.18 \\
\hline \multirow{2}{*}{$\mathrm{CO}_{2}$ emissions } & $\Psi 3$ & $\Psi 3$ & $\Psi 3$ & $\Psi 3$ & $\Psi 3$ & $\Psi 3$ & $\Psi 3$ & $\Psi 3$ & $\Psi 3$ & $\Psi 3$ \\
& - & - & - & - & - & - & - & - & - & - \\
\hline \multirow{2}{*}{ Self-sufficiency } & $\Psi 1$ & $\Psi 4$ & $\Psi 3$ & $\Psi 4$ & $\Psi 3$ & $\Psi 4$ & $\Psi 1$ & $\Psi 4$ & $\Psi 1$ & $\Psi 4$ \\
& 37.92 & 12.42 & - & 10.86 & - & 12.22 & 37.93 & 12.41 & 39.7 & 11.54 \\
\hline
\end{tabular}

\section{Discussion and Future Research Opportunities}

The proposed MP MADM approach for decision making under uncertainty can be transferred to other single-synthesizing MADM approaches, such as MAUT. The provided descriptions of Steps 2 and 3 are, however, based on the PROMETHEE-specific preference functions. One open question is whether preference thresholds should be aggregated across scenarios. In a real-world setting, thresholds are usually elicited from decision makers. If preference thresholds are to be elicited for each scenario, this can increase the complexity perceived by decision makers, reduce traceability of the evaluation, and thus impede the application of the proposed method in practice [104], depending on the number of scenarios, the number of criteria and the selection of preference functions (requiring up to two preference parameters) for a specific decision problem. One solution would be to calculate the preference thresholds from the decision table as a baseline and ask decision makers if they are comfortable with these settings. Likewise, dynamic preference thresholds, as proposed by [54], can be used.

We have adopted two MP aggregation variants proposed by [56]. Variant 2 is based on a discount factor. In [35], it is argued that uncertainty regarding future developments and their evaluations cannot be resolved by more sophisticated modeling per se, so that the valuation of advantages and disadvantages over time, even with a widely used method such as discounting, is problematic, because the choice of the discount factor $r$ cannot be validated [81]. In the sensitivity analysis regarding the discount factor $r$ in the case study, we found that the choice of $r$ did not have an impact on the rankings. However, depending on the distribution of net flows over time in a specific decision problem, rank reversals are possible [56]. Therefore, critical steps for the adequate consideration of uncertainties in our approach are: (1) defining the quantitative energy system model assumptions for different scenarios; (2) setting the parameters for multi-period aggregation methods; and (3) interpreting the results of the multi-period aggregation. More empirical research is needed to evaluate different MP aggregation variants based on confidence levels, discount factors, or other assumptions in terms of feasibility and value added for decision makers.

Related to the discussion of different single-period MADM approaches regarding their compensation of preference scores, any variant for the MP aggregation can also be compensatory, non-compensatory, or partially compensatory [67]. For example, the MP aggregation could also be realized with a MADM approach, as suggested by [51]. The 
choice should be dependent on the requirements of a specific decision problem regarding temporal compensation in path evaluations.

The proposed method allows external uncertainties in a deep uncertainty context to be considered, by enriching the problem-structuring and evaluation phases with a scenario planning technique. In this regard, MP-PROMETHEE-S can be clearly delineated from other proposed MP MADM methods under uncertainty, which either do not address uncertainties explicitly, consider them with scenario probabilities, or use Monte Carlo sampling. By specifying ranges for the path evaluations, MP-PROMETHEE-S allows the stability of evaluations of alternatives to be investigated, and thus evaluating the robustness of the ranking without requiring the specification of scenario probabilities.

It has been shown that more extensive problem structuring can lead to better understanding of decision problems, and supposedly, better decisions, in addition to the quantitative decision support provided by MADM methods $[10,104,105]$. In the proposed MP problem-structuring phase of MP-PROMETHEE-S, path dependencies of alternatives can be considered explicitly. It could be evaluated whether alternatives and path dependencies should be defined in accordance with the external scenarios, so that different transition paths are modeled in different scenarios, as proposed by [106]. Similarly, criteria weights could be defined depending on scenarios [74,76]. In this case, [83] has shown that presenting scenarios to decision makers can make the elicitation process of criteria weights more efficient. However, the increased efforts required for developing scenarios and the sensitivity analysis of a higher number of criteria weights may also deter decision makers and analysts from applying the method in practice [107].

Regarding limitations of the proposed method, the following restrictions can be mentioned: Decision support based on scenarios can be misleading because the possible future state-space cannot fully be explored, due to computational and epistemic limitations. Secondly, integrating social and political factors in energy scenarios is a challenge that is yet to be fully tackled $[32,108]$. The energy markets in particular have been influenced by many crises and tipping point situations such as the oil price shocks in the 1970s or political influences steering towards renewable energies in the 2000s. Therefore, these developments may be not covered adequately in an analysis, which is not a weakness of the method proposed, but a risk of the specific scenario description and design. Promising approaches for identifying relevant social and political developments are integrated approaches for energy scenario development and evaluation [2], socio-technical energy transition models [109], and the story-and-simulation approach [110].

Regarding the case of the bioenergy town Jühnde, the investigation into different scenarios can enrich the understanding, with an evaluation of the robustness of the ranking. Compared to the reference scenario described by [56], the alternatives' performance scores and ranks change under different scenario assumptions. However, in this case, the evaluation results are rather robust. For example, the best and worst transition paths' ranks as well as the next-best paths' ranks in the sensitivity analysis of criteria weights remain unchanged, regardless of scenario. The extensive modeling allows more facets of the problem to be captured, thus providing more extensive decision support.

In general, the integration of different decision support methodologies tends to increase the complexity and efforts for analysts. To adequately model decision problems under uncertainty, the analyst needs increased method knowledge for specialized problemstructuring methods under uncertainty [104]. In our case study with the limited local context of a town, the scenario analysis is simplified. Scenario analyses regarding the energy transition of whole states or communities of states are usually far more complex, including significantly more criteria [6] and technical options. Based on this single case study, it is challenging to evaluate the potential value added and increased effort of a more extensive decision support process-including scenario planning, energy system analysis, and MP MADM — without substantiating the evaluation with more empirical evidence. In general, applications of MP MADM approaches are limited so far. 
Future research extensions might include, for example, the connection to fuzzy set approaches, as is outlined in [39]. This could further enhance the method basis.

\section{Conclusions}

This paper presents an extension of an MP MADM method for evaluating transition paths under deep uncertainty (MP-PROMETHEE-S) and presents results for the case study of an energy transition in the German bioenergy town Jühnde. The application of the developed method in the case study exemplifies that it can help decision makers gain a better understanding of a decision problem by means of improved problem structuring and a more comprehensive evaluation regarding the robustness of the decision support provided. Due to the increased complexity and efforts in the decision support process, it should be carefully evaluated for any decision problem whether the potential benefits for decision makers can offset the increased effort of the decision support process. In the case study, the application of the new method leads to a robust evaluation of the best and worst transition paths, thus helping to reach energy policy goals with a more sustainable energy system. The specific contribution of this paper in outlining an external scenario extension for MP MADM approaches can be transferred to other contexts such as health care, tourism or education services, because flexible reaction of service design and management towards external changes and influences is likewise required in these contexts. Within the health care sector, for example, digitalization trends are leading to specific deep uncertainty settings, as outlined in [111], and scenario planning is already used today to deal with this. In addition, global disruptions such as COVID-19 lead to additional frictions and uncertainties [112]. Similar global events are expected to be relevant for the health care sector in the future too, even after COVID-19 [113]. Therefore, solving decision problems in complex service sectors such as health care is a possible application of the presented method innovation for deep uncertainty. In future research, other suitable MP MADM approaches, e.g., [49-52], could be extended to a setting with deep uncertainty, so that different MP MADM approaches can be compared, not only qualitatively, but also quantitatively, based on a common multi-period decision problem. Further research is required on the theory of multi-period decision problems with uncertainty, so that new approaches could be compared to existing ones, based on a common theory framework. For example, it would be interesting to compare MP MADM approaches that aggregate data from different periods before applying a MADM algorithm, e.g., [60,61], with approaches that aggregate data from different periods within the MADM algorithm, e.g., as is proposed in this paper. Another research avenue is to integrate a group decision framework in the new MP MADM approach, because for important strategic decisions, both the problem structuring (including, e.g., the modelling of future energy systems and the construction of relevant scenarios) and the evaluation of options are usually carried out in group settings.

Author Contributions: Conceptualization, T.W.; methodology, T.W.; software, T.W.; validation, M.K.; formal analysis, T.W.; investigation, T.W.; data curation, T.W.; writing-original draft preparation, T.W., M.K.; writing-review and editing, M.K.; visualization, T.W.; supervision, M.K. All authors have read and agreed to the published version of the manuscript.

Funding: This research received no external funding.

Institutional Review Board Statement: Not applicable.

Informed Consent Statement: Not applicable.

Data Availability Statement: The data presented in this study are available in this article.

Acknowledgments: Marcel Dumeier helped develop the basic energy system model used in this study, which we then extended to enable the consideration of scenarios.

Conflicts of Interest: The authors declare no conflict of interest. 


\section{References}

1. Grunwald, A.; Dieckhoff, C.; Fischedick, M.; Höffler, F.; Mayer, C.; Weimer-Jehle, W. Consulting with Energy Scenarios: Requirements for Scientific Policy Advice; Monograph Series on Science-based Policy Advice: München, Germany, 2016.

2. Weimer-Jehle, W.; Buchgeister, J.; Hauser, W.; Kosow, H.; Naegler, T.; Poganietz, W.-R.; Pregger, T.; Prehofer, S.; von Recklinghausen, A.; Schippl, J.; et al. Context scenarios and their usage for the construction of socio-technical energy scenarios. Energy 2016, 111, 956-970. [CrossRef]

3. Fortes, P.; Alvarenga, A.; Seixas, J.; Rodrigues, A.M.A. Long-term energy scenarios: Bridging the gap between socio-economic storylines and energy modeling. Technol. Forecast. Soc. Chang. 2015, 91, 161-178. [CrossRef]

4. Fitiwi, D.Z.; Lynch, M.; Bertsch, V. Enhanced network effects and stochastic modelling in generation expansion planning: Insights from an insular power system. Socio-Economic Plan. Sci. 2020, 71, 100859. [CrossRef]

5. Harjanne, A.; Korhonen, J. Abandoning the concept of renewable energy. Energy Policy 2019, 127, 330-340. [CrossRef]

6. Antunes, C.H.; Henriques, C.O. Multi-Objective Optimization and Multi-Criteria Analysis Models and Methods for Problems in the Energy Sector. In Multiple Criteria Decision Analysis: State of the Art Surveys, 2nd ed.; Greco, S., Ehrgott, M., Figueira, J., Eds.; Springer: New York, NY, USA, 2016; pp. 1067-1165. ISBN 978-1-4939-3093-7.

7. Narayanamoorthy, S.; Ramya, L.; Kalaiselvan, S.; Kureethara, J.V.; Kang, D. Use of DEMATEL and COPRAS method to select best alternative fuel for control of impact of greenhouse gas emissions. Socio-Econ. Plan. Sci. 2020, 100996, 100996. [CrossRef]

8. Kowalski, K.; Stagl, S.; Madlener, R.; Omann, I. Sustainable energy futures: Methodological challenges in combining scenarios and participatory multi-criteria analysis. Eur. J. Oper. Res. 2009, 197, 1063-1074. [CrossRef]

9. Volkart, K.; Weidmann, N.; Bauer, C.; Hirschberg, S. Multi-criteria decision analysis of energy system transformation pathways: A case study for Switzerland. Energy Policy 2017, 106, 155-168. [CrossRef]

10. Witt, T.; Dumeier, M.; Geldermann, J. Combining scenario planning, energy system analysis, and multi-criteria analysis to develop and evaluate energy scenarios. J. Clean. Prod. 2020, 242, 118414. [CrossRef]

11. Løken, E. Use of multicriteria decision analysis methods for energy planning problems. Renew. Sustain. Energy Rev. 2007, 11, 1584-1595. [CrossRef]

12. Mardani, A.; Zavadskas, E.K.; Khalifah, Z.; Zakuan, N.; Jusoh, A.; Nor, K.M.; Khoshnoudi, M. A review of multi-criteria decision-making applications to solve energy management problems: Two decades from 1995 to 2015. Renew. Sustain. Energy Rev. 2017, 71, 216-256. [CrossRef]

13. Diaz-Balteiro, L.; González-Pachón, J.; Romero, C. Measuring systems sustainability with multi-criteria methods: A critical review. Eur. J. Oper. Res. 2017, 258, 607-616. [CrossRef]

14. Janeiro, L.; Patel, M.K. Choosing sustainable technologies. Implications of the underlying sustainability paradigm in the decision-making process. J. Clean. Prod. 2015, 105, 438-446. [CrossRef]

15. Kumar, A.; Sah, B.; Singh, A.R.; Deng, Y.; He, X.; Kumar, P.; Bansal, R. A review of multi criteria decision making (MCDM) towards sustainable renewable energy development. Renew. Sustain. Energy Rev. 2017, 69, 596-609. [CrossRef]

16. Wang, J.-J.; Jing, Y.-Y.; Zhang, C.-F.; Zhao, J.-H. Review on multi-criteria decision analysis aid in sustainable energy decisionmaking. Renew. Sustain. Energy Rev. 2009, 13, 2263-2278. [CrossRef]

17. Kilic, H.S.; Yalcin, A.S. Comparison of municipalities considering environmental sustainability via neutrosophic DEMATEL based TOPSIS. Socio-Economic Plan. Sci. 2021, 75, 100827. [CrossRef]

18. Cuoghi, K.G.; Leoneti, A.B. A group MCDA method for aiding decision-making of complex problems in public sector: The case of Belo Monte Dam. Socio-Economic Plan. Sci. 2019, 68, 100625. [CrossRef]

19. Manzini, F.; Islas, J.; Macías, P. Model for evaluating the environmental sustainability of energy projects. Technol. Forecast. Soc. Chang. 2011, 78, 931-944. [CrossRef]

20. Yeo, M.; Kim, Y. Changes of the carbon dioxide emissions and the overshoot ratio resulting from the implementation of the 2nd Energy Master Plan in the Republic of Korea. Energy Policy 2016, 96, 241-250. [CrossRef]

21. Li, W.; Yang, G.; Li, X.; Sun, T.; Wang, J. Cluster analysis of the relationship between carbon dioxide emissions and economic growth. J. Clean. Prod. 2019, 225, 459-471. [CrossRef]

22. Mardani, A.; Liao, H.; Nilashi, M.; Alrasheedi, M.; Cavallaro, F. A multi-stage method to predict carbon dioxide emissions using dimensionality reduction, clustering, and machine learning techniques. J. Clean. Prod. 2020, 275, 122942. [CrossRef]

23. Marra, A.; Colantonio, E. The path to renewable energy consumption in the European Union through drivers and barriers: A panel vector autoregressive approach. Socio-Economic Plan. Sci. 2020, 100958, 100958. [CrossRef]

24. Dyer, J.S. Multiattribute Utility Theory (MAUT). In Multiple Criteria Decision Analysis: State of the Art Surveys, 2nd ed.; Greco, S., Ehrgott, M., Figueira, J., Eds.; Springer: New York, NY, USA, 2016; pp. 285-314. ISBN 978-1-4939-3093-7.

25. Brans, J.-P.; Smet, Y. de. PROMETHEE Methods. In Multiple Criteria Decision Analysis: State of the Art Surveys, 2nd ed.; Greco, S., Ehrgott, M., Figueira, J., Eds.; Springer: New York, NY, USA, 2016; pp. 187-219. ISBN 978-1-4939-3093-7.

26. Saaty, T.L. The Analytic Hierarchy and Analytic Network Processes for the Measurement of Intangible Criteria and for Decision Making. In Multiple Criteria Decision Analysis: State of the Art Surveys, 2nd ed.; Greco, S., Ehrgott, M., Figueira, J., Eds.; Springer: New York, NY, USA, 2016; pp. 363-420. ISBN 978-1-4939-3093-7.

27. Figueira, J.R.; Mousseau, V.; Roy, B. ELECTRE Methods. In Multiple Criteria Decision Analysis: State of the Art Surveys, 2nd ed.; Greco, S., Ehrgott, M., Figueira, J., Eds.; Springer: New York, NY, USA, 2016; pp. 155-186. ISBN 978-1-4939-3093-7. 
28. Hämäläinen, R.P.; Seppäläinen, T.O. The analytic network process in energy policy planning. Socio-Econ. Plan. Sci. 1986, 20, 399-405. [CrossRef]

29. Belton, V.; Stewart, T.J. Multiple Criteria Decision Analysis: An Integrated Approach, 2. Print; Kluwer Academic Publishers: Boston, MA, USA, 2003; ISBN 0-7923-7505-X.

30. Yu, P.-L.; Chen, Y.-C. Dynamic multiple criteria decision making in changeable spaces: From habitual domains to innovation dynamics. Ann. Oper. Res. 2012, 197, 201-220. [CrossRef]

31. Verbong, G.; Geels, F. Exploring sustainability transitions in the electricity sector with socio-technical pathways. Technol. Forecast. Soc. Chang. 2010, 77, 1214-1221. [CrossRef]

32. Pfenninger, S.; Hawkes, A.; Keirstead, J. Energy systems modeling for twenty-first century energy challenges. Renew. Sustain. Energy Rev. 2014, 33, 74-86. [CrossRef]

33. Ram, C.; Montibeller, G. Exploring the impact of evaluating strategic options in a scenario-based multi-criteria framework. Technol. Forecast. Soc. Chang. 2013, 80, 657-672. [CrossRef]

34. Durbach, I.N.; Stewart, T.J. Modeling uncertainty in multi-criteria decision analysis. Eur. J. Oper. Res. 2012, 223, 1-14. [CrossRef]

35. French, S. Uncertainty and Imprecision: Modelling and Analysis. J. Oper. Res. Soc. 1995, 46, 70-79. [CrossRef]

36. Van Der Pas, J.W.G.M.; Walker, W.E.; Marchau, V.A.W.J.; Van Wee, G.P.; Agusdinata, D.B. Exploratory MCDA for handling deep uncertainties: The case of intelligent speed adaptation implementation. J. Multi-Criteria Decis. Anal. 2010, 17, 1-23. [CrossRef]

37. Stewart, T.J.; Durbach, I.N. Dealing with Uncertainties in MCDA. In Multiple Criteria Decision Analysis: State of the Art Surveys, 2nd ed.; Greco, S., Ehrgott, M., Figueira, J., Eds.; Springer: New York, NY, USA, 2016; pp. 467-496. ISBN 978-1-4939-3093-7.

38. Zimmermann, H.-J. Fuzzy set theory. Wiley Interdiscip. Rev. Comput. Stat. 2010, 2, 317-332. [CrossRef]

39. Kaya, I.; Çolak, M.; Terzi, F. A comprehensive review of fuzzy multi criteria decision making methodologies for energy policy making. Energy Strat. Rev. 2019, 24, 207-228. [CrossRef]

40. Greco, S.; Matarazzo, B.; Slowinski, R. Rough sets theory for multicriteria decision analysis. Eur. J. Oper. Res. 2001, 129, 1-47. [CrossRef]

41. van der Heijden, K. Scenarios: The Art of Strategic Conversation, 2nd ed.; Wiley: Chichester, UK, 2009; ISBN 0-470-02368-6.

42. Goodwin, P.; Wright, G. The limits of forecasting methods in anticipating rare events. Technol. Forecast. Soc. Chang. 2010, 77, 355-368. [CrossRef]

43. Gausemeier, J.; Fink, A.; Schlake, O. Scenario Management: An Approach to Develop Future Potentials. Technol. Forecast. Soc. Chang. 1998, 59, 111-130. [CrossRef]

44. Spaniol, M.J.; Rowland, N.J. Defining scenario. Futures Foresight Sci. 2018, 1, e3. [CrossRef]

45. Connolly, D.; Lund, H.; Mathiesen, B.; Leahy, M. A review of computer tools for analysing the integration of renewable energy into various energy systems. Appl. Energy 2010, 87, 1059-1082. [CrossRef]

46. Balash, P.; Nichols, C.; Victor, N. Multi-regional evaluation of the U.S. electricity sector under technology and policy uncertainties: Findings from MARKAL EPA9rUS modeling. Socio-Econ. Plan. Sci. 2013, 47, 89-119. [CrossRef]

47. Bendoly, E.; Bachrach, D.G. A process-based model for priority convergence in multi-period group decision-making. Eur. J. Oper. Res. 2003, 148, 534-545. [CrossRef]

48. Frini, A.; Guitouni, A.; Martel, J.-M. A general decomposition approach for multi-criteria decision trees. Eur. J. Oper. Res. 2012, 220, 452-460. [CrossRef]

49. Frini, A. A multi-criteria multi-period approach for energy project selection in sustainable development con-text. In Proceedings of the 2014 First International Conference on Green Energy ICGE 2014, Sfax, Tunisia, 25-27 March 2014; pp. 65-71, ISBN 978-1-4799-3602-1.

50. Frini, A.; Benamor, S. A TOPSIS multi-criteria multi-period approach for selecting projects in sustainable development context. In Proceedings of the 2015 International Conference on Industrial Engineering and Operations Management (IEOM), Dubai, United Arab Emirates, 3-5 March 2015; Volume Dubai, pp. 1-9.

51. Frini, A.; Benamor, S. Making Decisions in a Sustainable Development Context: A State-of-the-Art Survey and Proposal of a Multi-period Single Synthesizing Criterion Approach. Comput. Econ. 2017, 52, 341-385. [CrossRef]

52. Frini, A.; Ben Amor, S. MUPOM: A multi-criteria multi-period outranking method for decision-making in sustainable development context. Environ. Impact Assess. Rev. 2019, 76, 10-25. [CrossRef]

53. Yu, X.; Xu, Z.; Hu, J.; Liu, S. Systematic decision making: A extended multi-criteria decision making model. Technol. Econ. Dev. Econ. 2017, 23, 157-177. [CrossRef]

54. Banamar, I.; De Smet, Y. An extension of PROMETHEE II to temporal evaluations. Int. J. Multicrit. Decis. Mak. 2018, 7, 298. [CrossRef]

55. Urli, B.; Frini, A.; Ben Amor, S. PROMETHEE-MP: A generalisation of PROMETHEE for multi-period evaluations under uncertainty. Int. J. Multicriteria Decis. Mak. 2019, 8, 13. [CrossRef]

56. Witt, T.; Dumeier, M.; Geldermann, J. Multi-criteria Evaluation of the Transition of Power Generation Sys-tems. In Proceedings of the Multikriterielle Optimierung und Entscheidungsunterstützung, Tagungsband GOR Entscheidungstheorie und -Praxis 2018, Kaiserslautern, Germany, 1-2 March 2018; Küfer, K.-H., Ruzika, S., Halffmann, P., Eds.; Springer Gabler: Wiesbaden, Germany, 2019; pp. 121-141, ISBN 978-3-658-27041-4. 
57. Ziemba, P.; Jankowski, J.; Watróbski, J. Dynamic Decision Support in the Internet Marketing Management. In Transactions on Computational Collective Intelligence XXIX; Nguyen, N.T., Kowalczyk, R., Eds.; Springer: Berlin/Heidelberg, Germany, 2018; pp. 39-68.

58. Webster, J.; Watson, R.T. Analyzing the Past to Prepare for the Future: Writing a literature Review. Manage Inform. Syst. Q. 2002, $26,13-23$.

59. Denyer, D.; Tranfield, D. Producing a Systematic Review. In The Sage Handbook of Organizational Research Methods; Buchanan, D.A., Bryman, A., Eds.; Sage Publications Inc.: Thousand Oaks, CA, USA, 2011; pp. 671-689. ISBN 978-1-4462-0064-3.

60. Jassbi, J.J.; Ribeiro, R.; Varela, L.R. Dynamic MCDM with future knowledge for supplier selection. J. Decis. Syst. 2014, 23, 232-248. [CrossRef]

61. Campanella, G.; Ribeiro, R. A framework for dynamic multiple-criteria decision making. Decis. Support. Syst. 2011, 52, 52-60. [CrossRef]

62. Kosow, H. New outlooks in traceability and consistency of integrated scenarios. Eur. J. Futur. Res. 2015, 3, 1-12. [CrossRef]

63. Knoke, T.; Gosling, E.; Paul, C. Use and misuse of the net present value in environmental studies. Ecol. Econ. 2020, 174, 106664. [CrossRef]

64. Dotoli, M.; Epicoco, N.; Falagario, M. Multi-Criteria Decision Making techniques for the management of public procurement tenders: A case study. Appl. Soft Comput. 2020, 88, 106064. [CrossRef]

65. Schröder, T.; Lauven, L.-P.; Beyer, B.; Lerche, N.; Geldermann, J. Using PROMETHEE to assess bioenergy pathways. Central Eur. J. Oper. Res. 2018, 27, 287-309. [CrossRef]

66. Munda, G. "Measuring Sustainability": A Multi-Criterion Framework. Environ. Dev. Sustain. 2005, 7, 117-134. [CrossRef]

67. Guitouni, A.; Martel, J.-M. Tentative guidelines to help choosing an appropriate MCDM method. Eur. J. Oper. Res. 1998, 109, 501-521. [CrossRef]

68. Oberschmidt, J.; Geldermann, J.; Ludwig, J.; Schmehl, M. Modified PROMETHEE approach for assessing energy technologies. Int. J. Energy Sect. Manag. 2010, 4, 183-212. [CrossRef]

69. Diakoulaki, D.; Karangelis, F. Multi-criteria decision analysis and cost-benefit analysis of alternative scenarios for the power generation sector in Greece. Renew. Sustain. Energy Rev. 2007, 11, 716-727. [CrossRef]

70. Tsoutsos, T.; Drandaki, M.; Frantzeskaki, N.; Iosifidis, E.; Kiosses, I. Sustainable energy planning by using multi-criteria analysis application in the island of Crete. Energy Policy 2009, 37, 1587-1600. [CrossRef]

71. Doukas, H.C.; Andreas, B.M.; Psarras, J.E. Multi-criteria decision aid for the formulation of sustainable technological energy priorities using linguistic variables. Eur. J. Oper. Res. 2007, 182, 844-855. [CrossRef]

72. French, S.; Geldermann, J. The varied contexts of environmental decision problems and their implications for decision support. Environ. Sci. Policy 2005, 8, 378-391. [CrossRef]

73. Brans, J.P.; Vincke, P. Note-A Preference Ranking Organisation Method: The PROMETHEE Method for Multiple Criteria Decision-Making. Manag. Sci. 1985, 31, 647-656. [CrossRef]

74. Montibeller, G.; Gummer, H.; Tumidei, D. Combining scenario planning and multi-criteria decision analysis in practice. J. Multi-Crit. Decis. Anal. 2006, 14, 5-20. [CrossRef]

75. Stewart, T.J.; French, S.; Rios, J. Integrating multicriteria decision analysis and scenario planning-Review and extension. Omega 2013, 41, 679-688. [CrossRef]

76. Durbach, I.N.; Stewart, T.J. Probability and Beyond: Including Uncertainties in Decision Analysis. In Behavioral Operational Research; White, L., Kunc, M., Burger, K., Malpass, J., Eds.; Springer International Publishing: Cham, Switzerland, 2020 ; pp. 75-91. ISBN 978-3-030-25404-9.

77. Vadén, T.; Majava, A.; Toivanen, T.; Järvensivu, P.; Hakala, E.; Eronen, J. To continue to burn something? Technological, economic and political path dependencies in district heating in Helsinki, Finland. Energy Res. Soc. Sci. 2019, 58, 101270. [CrossRef]

78. Kuper, G.; van Soest, D.P. Path-dependency and input substitution: Implications for energy policy modelling. Energy Econ. 2003, 25, 397-407. [CrossRef]

79. Daystar, J.; Venditti, R.; Kelley, S.S. Dynamic greenhouse gas accounting for cellulosic biofuels: Implications of time based methodology decisions. Int. J. Life Cycle Assess. 2017, 22, 812-826. [CrossRef]

80. Cropper, M.L.; Aydede, S.K.; Portney, P.R. Preferences for life saving programs: How the public discounts time and age. J. Risk Uncertain. 1994, 8, 243-265. [CrossRef]

81. Bell, M.L.; Hobbs, B.F.; Ellis, H. The use of multi-criteria decision-making methods in the integrated assessment of climate change: Implications for IA practitioners. Socio-Economic Plan. Sci. 2003, 37, 289-316. [CrossRef]

82. Weitzman, M.L. Why the Far-Distant Future Should Be Discounted at Its Lowest Possible Rate. J. Environ. Econ. Manag. 1998, 36, 201-208. [CrossRef]

83. Ram, C. Scenario presentation and scenario generation in multi-criteria assessments: An exploratory study. Technol. Forecast. Soc. Chang. 2020, 151, 119850. [CrossRef]

84. Lerche, N.; Wilkens, I.; Schmehl, M.; Eigner-Thiel, S.; Geldermann, J. Using methods of Multi-Criteria Decision Making to provide decision support concerning local bioenergy projects. Socio-Econ. Plan. Sci. 2019, 68, 100594. [CrossRef]

85. Schär, S.; Geldermann, J. Adopting Multiactor Multicriteria Analysis for the Evaluation of Energy Scenarios. Sustainability 2021, 13, 2594. [CrossRef] 
86. Kim, S.-H.; Ahn, B.-S. Group decision making procedure considering preference strength under incomplete information. Comput. Oper. Res. 1997, 24, 1101-1112. [CrossRef]

87. Mareschal, B.; Brans, J.P.; Macharis, C. The GDSS PROMETHEE procedure: A PROMETHEE-GAIA based procedure for group decision support. J. Decis. Syst. 1998, 7, 283-307.

88. Haralambopoulos, D.; Polatidis, H. Renewable energy projects: Structuring a multi-criteria group decision-making framework. Renew. Energy 2003, 28, 961-973. [CrossRef]

89. Nestle, U.; Kunz, C. Studienvergleich: Stromgestehungskosten Verschiedener Erzeugungstechnologien; Forschungsradar EnergiewendeMetaanalyse: Berlin, Germany, 2014.

90. Wissel, S.; Rath-Nagel, M.; Blesl, U.; Fahl, U.; Voß, A. Stromerzeugungskosten im Vergleich; Institut für Energiewirtschaft und Rationelle Energieanwendung: Stuttgart, Germany, 2008.

91. Bundesverband der Energie- und Wasserwirtschaft, e.V. BDEW-Strompreisanalyse Januar 2021. Available online: https:/ /www. bdew.de/service/daten-und-grafiken/bdew-strompreisanalyse/ (accessed on 28 May 2021).

92. Statistisches Bundesamt. Index der Erzeugerpreise gewerblicher Produkte (Inlandsabsatz) nach dem Güterverzeichnis für Produktionsstatistiken: Lange Reihen der Fachserie 17, Reihe 2 von Januar 2005 bis April 2021. Available online: https://www.destatis.de/DE/Themen/Wirtschaft/Preise/Erzeugerpreisindex-gewerbliche-Produkte/Publikationen/ Downloads-Erzeugerpreise/erzeugerpreise-lange-reihen-pdf-5612401.pdf?_blob=publicationFile (accessed on 28 May 2021).

93. Genske, D.; Jödecke, T.; Ruff, A.; Porsche, L. Nutzung Städtischer Freiflächen für Erneuerbare Energien: Ein Projekt des FORSCHUNGSPROGRAMMS "Experimenteller Wohnungs- und Städtebau" (ExWoSt) des Bundesministeriums für Verkehr, Bau und Stadtentwicklung (BMVBS) und des Bundesamtes für Bauwesen und Raumordnung (BBR); Bundesamt für Bauwesen und Raumordnung: Bonn, Germany, 2009; ISBN 978-3-87994-044-8.

94. Icha, P. Entwicklung der spezifischen Kohlendioxid-Emissionen des deutschen Strommix in den Jahren 1990-2016. Available online: https://www.umweltbundesamt.de/publikationen/entwicklung-der-spezifischen-kohlendioxid-3 (accessed on 28 May 2021).

95. ED Netze GmbH. Lastprofile der ED Netze GmbH. Available online: https:/ / www.ednetze.de/kunde/lieferanten/lastprofiletemperaturtabellen/ (accessed on 28 May 2021).

96. 50Hertz Transmission GmbH. Zeitlicher Verlauf der EEG-Stromeinspeisung. Available online: http://www.50hertz.com/de/ EEG/Veroeffentlichung-EEG-Daten/Verlauf-EEG-Stromeinspeisung (accessed on 27 October 2017).

97. Weimer-Jehle, W.; Vögele, S.; Hauser, W.; Kosow, H.; Poganietz, W.-R.; Prehofer, S. Socio-technical energy scenarios: State-of-theart and CIB-based approaches. Clim. Chang. 2020, 162, 1723-1741. [CrossRef]

98. Weimer-Jehle, W. Cross-impact balances: A system-theoretical approach to cross-impact analysis. Technol. Forecast. Soc. Chang. 2006, 73, 334-361. [CrossRef]

99. Weimer-Jehle, W. ScenarioWizard 4.3: Constructing Consistent Scenarios Using Cross-Impact Balance Analysis. Available online: http:/ / www.cross-impact.org/ressourcen/ScenarioWizardManual_en.pdf (accessed on 5 August 2020).

100. de Bruin, Y.B.; Lequarre, A.-S.; McCourt, J.; Clevestig, P.; Pigazzani, F.; Jeddi, M.Z.; Colosio, C.; Goulart, M. Initial impacts of global risk mitigation measures taken during the combatting of the COVID-19 pandemic. Saf. Sci. 2020, 128, 104773. [CrossRef] [PubMed]

101. Ivanov, D. Predicting the impacts of epidemic outbreaks on global supply chains: A simulation-based analysis on the coronavirus outbreak (COVID-19/SARS-CoV-2) case. Transp. Res. Part E Logist. Transp. Rev. 2020, 136, 101922. [CrossRef] [PubMed]

102. Kemp-Benedict, E. Converting qualitative assessments to quantitative assumptions: Bayes' rule and the pundit's wager. Technological Forecasting and Social Change 2010, 77, 167-171. [CrossRef]

103. Madlener, R.; Alcott, B. Energy rebound and economic growth: A review of the main issues and re-search needs. Energy 2009, 34, 370-376. [CrossRef]

104. Marttunen, M.; Lienert, J.; Belton, V. Structuring problems for Multi-Criteria Decision Analysis in practice: A literature review of method combinations. Eur. J. Oper. Res. 2017, 263, 1-17. [CrossRef]

105. Witt, T. Transparency in Energy Scenario Studies: Survey of Different Approaches Combining Scenario Planning, Energy System Analysis, and Multi-criteria Analysis. In Proceedings of the 9th International Conference on Smart Cities and Green ICT Systems, Prague, Czech Republic, 2-4 May 2020; Klein, C., Helfert, M., Eds.; SCITEPRESS: Setúbal, Portugal, 2020; pp. $114-121$.

106. Comes, T.; Hiete, M.; Schultmann, F. An Approach to Multi-Criteria Decision Problems Under Severe Uncertainty. J. Multi-Crit. Decis. Anal. 2013, 20, 29-48. [CrossRef]

107. Grant, R.M. Strategic planning in a turbulent environment: Evidence from the oil majors. Strat. Manag. J. 2003, 24, 491-517. [CrossRef]

108. Schubert, D.K.J.; Thuß, S.; Möst, D. Does political and social feasibility matter in energy scenarios? Energy Res. Soc. Sci. 2015, 7, 43-54. [CrossRef]

109. Li, F.G.; Trutnevyte, E.; Strachan, N. A review of socio-technical energy transition (STET) models. Technol. Forecast. Soc. Chang. 2015, 100, 290-305. [CrossRef]

110. Alcamo, J. The SAS Approach: Combining Qualitative and Quantitative Knowledge in Environmental Sce-narios. In Environmental Futures: The Practice of Environmental Scenario Analysis, 1st ed.; Alcamo, J., Ed.; Elsevier: Amsterdam, The Netherlands, 2008; pp. 123-150; ISBN 978-0-444-53293-0. 
111. Jhala, K.; Tasi, M.C.; Seltzer, S.E. Scenario Planning: Radiology Optimization for the New Era of Health Care Economics. J. Am. Coll. Radiol. 2020, 17, 190-193. [CrossRef] [PubMed]

112. Edejer, T.T.-T.; Hanssen, O.; Mirelman, A.; Verboom, P.; Lolong, G.; Watson, O.J.; Boulanger, L.L.; Soucat, A. Projected health-care resource needs for an effective response to COVID-19 in 73 low-income and middle-income countries: A modelling study. Lancet Glob. Health 2020, 8, e1372-e1379. [CrossRef]

113. Anderson, M.; Pitchforth, E.; Asaria, M.; Brayne, C.; Casadei, B.; Charlesworth, A.; Coulter, A.; Franklin, B.D.; Donaldson, C.; Drummond, M.; et al. LSE-Lancet Commission on the future of the NHS: Re-laying the foundations for an equitable and efficient health and care service after COVID-19. Lancet 2021, 397, 1915-1978. [CrossRef] 